\title{
A Success Model or an Uneasy Future for Peacebuilding? Post-Conflict Consolidation of Peace in East Timor
}

\author{
Hideaki Asahi
}

\begin{abstract}
The case of East Timor is distinct in that it offers both its own specifics and a common perspective widely shared among peacebuilders. Its unique trajectory of developments could be more succinctly understood through a four-dimensional taxonomy: "givens," the past, the present, and the future. Three "givens" represent the unique historical, political, and geographical dimensions of the country. Its distinct position in the historical context of UN peace operations is marked not only by reaffirmed relevance as a "success" model despite its increasingly complicated form, but also by unprecedented challenges for consent of the host country and adoption of local wisdom. However, East Timor is subject to pitfalls in the progress of peacebuilding. Also, as time passes it may face changing agendas and disquieting woes.
\end{abstract}

Keywords peacebuilding, state-building, nation-building, "start from scratch," "getting to Denmark"

\section{Introduction}

The whole process of United Nations (UN) peace operations, ${ }^{1}$ including the stage of post-conflict consolidation of peace, which East Timor, or Timor-Leste, ${ }^{2}$ has undergone to date, is unique in many ways and contrasts with other cases underway around the world. In order to examine how it differs and what it shares in common with the others, several salient points need to be made.

\section{Three "Givens" Conditioning Peacebuilding in East Timor}

There are three "given" factors that condition the policy framework of peacebuilding in East Timor and that have truly led to where it now stands (Asahi 
$2012 ; 2015,267-269)$.

\section{"Start from Scratch"}

First, it seems that with the passing of two decades since the early 1990s, full of practices on the ground and theoretical studies in academia, there is now a convergence of opinions about the notion of peacebuilding. That is, peacebuilding is tantamount to state building. Or, in other words, as Roland Paris defines it, "peacebuilding is top-down, state-centric processes with a structural focus on putting in place the central, and national-level institutions of the state" (Paris and Sisk 2009, 1-11). I argue that, in East Timor, peacebuilding means not only state building, but also nation building. As I will discuss later, the latter reflects a unique historical trajectory that the country has experienced over the past quarter century. Both Kosovo and South Sudan are classified in this category. Libya falls in the same category with the reconstruction of the state institutions being urgent after its total destruction following the collapse of the Kaddafi regime. In this connection, Francis Fukuyama maintained that "nations-that is to say, communities of shared values, traditions, and historical memory-by this argument are never built, particularly by outsiders; rather, they evolve out of an unplanned historical-evolutionary process" (Fukuyama 2006, 3).

All of these cases have some common denominators. First, these countries lack experience of self-rule within their own territories. Second, they have had neither effective government institutions of their own, nor laws, regulations, and other normative codes to rule their citizens. Kamalesh Sharma, Special Representative of the Secretary-General (SRSG) of the United Nations Mission of Support in East Timor (UNMISET), the UN's peacebuilding mission after the independence of East Timor, immediately detected that the core nature of his assignments boils down to a slogan of "start from scratch."

In addition, there is another deficit of peacebuilding; that is, the lack of national coherence or absence of national unity that weave together disparate local communities. The premature statehood marked by these deficits truly complicated the task of peacebuilding in East Timor although it was fortunately free from social, ethnic, or linguistic cleavages. It is not surprising, therefore, that as I oversaw the tally of the 2012 general elections, no candidates, neither individuals nor political parties, were able to secure votes evenly across all districts under the sole national constituency system (Asahi 2012, 5-10). These harsh realities underlie the very reason why Sharma insisted on the positive effects that the expansion and maintenance of incipient road networks would have in connecting local communities separated historically and scattered physically due to steep mountainous terrain. It is in this context that Sharma highly appreciated the contributions made by Japan's engineering contingents, locally nicknamed JEG, dispatched to participate in peacekeeping activities under the UNMISET. The implications of their contributions in fact were not just 
economic, but also political and social.

Furthermore, Fukuyama examined the transitional process of political development that evolved in history from tribal-level to state-level societies and maintained that mountainous terrain held back smooth transitions and often prevented state formation (Fukuyama 2011, 92). His insights provide good hints at where East Timor stands in terms of the historical stage of political development and why it does so.

\section{"Good Neighborhood" Relationships}

The second distinctive factor for East Timor relates to the positive effects of what could be called a "good neighborhood," as opposed to Michael Ignatieff's "bad neighborhood" effect to peacebuilding (Ignatieff 2003, 313-315; Knaus and Cox 2005, 39-53). I observe that, generally speaking, the causes and nature of conflicts truly condition the size and scope of post-conflict peacebuilding. In this regard, East Timor is in a positive situation in contrast to Bosnia-Herzegovina, for instance, where warring parties were compelled not only to live together in the wake of conflicts while sharing the same political as well as living space, but also to compromise over differences in order to overcome difficulties. I argue that the East Timorese have enjoyed the benefits of a more politically benign environment that was brought into being after the total departure of the Indonesian national armed forces (TNI), which was an overarching military menace to local populations on the island. As Roland Paris argues, we saw the same nature of threats by external forces in both Angola and Mozambique, where peace was eventually restored after the withdrawal of the external South African armed forces (Paris 2005, 772-774).

Indonesia, which once repressed East Timor, has now transitioned from military rule to democracy, and has also become diplomatically friendly. Australia, another powerful neighbor in the sub-region, also holds the same diplomatic posture toward East Timor. But Australia is now in a harsh territorial dispute over offshore gas fields with East Timor (Economist 2013, 24). The geographical location of the country as part of Southeast Asia is recognized internationally, and tacit acceptance of its application for accession to the Association of Southeast Asian Nations (ASEAN) benefits East Timor. These developments truly contribute to peacebuilding in East Timor.

\section{Sizes Matter}

The third factor concerns the size of East Timor in terms of population and area. James Dobbins argues that there are several necessary conditions if UNsanctioned peacebuilding is to do well. Besides the size of operations, Dobbins points to three other advantages the "UN Model" of peace operations enjoys as opposed to the so-called "U.S. Model," namely (1) institutionalized learning and a stock of knowledge; (2) a higher success rate combined with economized 
operational costs; and (3) relatively easily acquired authorization of military action (Dobbins et al. 2005, 243-251). I argue that all of these advantages, including the relatively small operational size, apply to the case of East Timor. East Slavonia and Bosnia, where a UN temporary administration was once in place, have this point in common.

The influence of a reasonably small population may also positively affect the development of an electoral democracy if fortunately combined with other required preconditions. Having participated in national election monitoring both in 2007 and 2012, I was impressed twice that the East Timorese people performed well in managing an "indirect" electoral democracy, although much larger in size compared with "direct" democracy once practiced in Athens and other city-states of Ancient Greece (Asahi 2012, 5-10). What I call "indirect" electoral democracy has apparently been brought into being in East Timor; resting on the positive effects generated by the combination of a comfortable physical distance and mentally intimate relationships among community residents.

Moreover, Greg Willis, author of Why States Recover, offers a very interesting perspective that is as follows: "The physical size of a small nation, while making possible close and constant contacts of political leaders with their citizens, presumably lends itself to the formation of a functional state and the realization of political freedom" (Wills 2014, 525).

\section{A Historical Perspective}

To elucidate its uniqueness, I would next like to place East Timor in a historical context of UN peace operations. And, drawing on Simon Chesterman's (2007, 192-216) lucid analytical framework, I attempt to explain that it offers plenty of thoughtful inputs in terms of scope, depth, length, and complexities of operation.

The historical genesis of East Timor dates back to post-colonial struggles for independence. In 1975, a political coup occurred in Portugal; and, as a result, the Portuguese colonial regime broke down and almost all its overseas colonial territories were abandoned. This is what Samuel Huntington famously pointed to as the trigger of the "Third Wave" of democratization that swept the world for the decades that followed (Huntington 1993). East Timor was also part of Portugal's ex-colonial territories. Local political groups, if not united, immediately rose up to declare independence. But it was short-lived and utterly suppressed by the TNI which soon came ashore, crushed the local independent movement, and placed the island under direct military control. Thereafter, clandestine armed resistance raged against the military rule and independence movements went underground both on the home front and abroad toward the end of the twentieth century.

Thanks to fortunate diplomatic progress made through the tripartite negotiations among Portugal, Indonesia, and the UN, as an honest broker in 
between, it was decided in May 1999 that what was called "popular consultation," or a referendum by the Timorese population, would be forthcoming. In fact, local voting was carried out in August 1999 under the auspices of UN electoral supervision. The voting results betrayed the predictions and turned out in favor of independence with an overwhelming majority, rather than autonomous rule within Indonesia. But a humanitarian disaster suddenly emerged despite the UN presence with a trigger of violence and fear stoked by the unexpected outcome. Violent acts and atrocities were perpetrated and escalated not only by local militias but also by the Indonesian military on the ground, both of which were alleged to be in league.

The international community responded rather swiftly to the humanitarian tragedy. The UN Security Council passed a binding resolution in order to quell the rampages and restore peace, authorizing the Chapter VII mandate to deploy multinational forces, to be known as the International Force for East Timor (INTERFET), which staved off the crisis and contributed, in turn, to fewer casualties than anticipated in a UN scenario that I heard directly or indirectly from those in New York who were informed of the volatile situation in East Timor (Asahi 2015, 175-176). Obviously, the prompt action was not only a result of the preliminary consultations repeatedly conducted among those countries interested in the evolving situation in East Timor. Preparations were also deliberately made at the UN headquarters, taking advantage of similar preparatory work done for Kosovo in the immediate past (Kawakami 2003, 43).

\section{Reaffirmed Relevance of UN Peace Operations}

To elaborate on this process, it is assumed that both the UN member states and the then UN Secretary-General, Kofi Annan, apparently shared not only the same concerns about the ill-conceived image of UN peacekeeping then widely spread in the wake of some failures, but also the same political and strategic interests to bring it back on track.

In this connection, I argue that East Timor's experience is unique in two ways. First, as is well-known among students of political science and international relations, the practice of UN peace operations has had a turbulent history of more than two decades. There were ups and downs, especially throughout the 1990s. As not only Paul Kennedy unequivocally pointed out in his widelyread book The Parliament of Man, but Kofi Annan also admitted later in his memoir entitled Interventions, the international community had witnessed three historic UN blunders: Somalia (1992), Rwanda (1994), and Srebrenica in Bosnia (1995) (Kennedy 2006, 95; Annan 2012, 32). In hindsight, there was no peace to protect. Subsequently, because of the "overstretch" and "fatigue" of international support, UN peacekeeping receded to its lowest ebb toward the end of the 1990s. 
In addition, NATO's military intervention of early 1999 in Kosovo not only intentionally omitted Security Council resolutions, but blatantly undercut its legitimate power to sanction military action.

As mentioned above, it is in the aftermath of those setbacks experienced in the series of UN peacekeeping operations that the international community faced a new challenge in East Timor. The advent of a peace operation in East Timor was therefore taken seriously as a critical test for continued relevance or overdue irrelevance of UN-led peace operations; or in other words, for an impending need for new options (Power 2008, 318). The fact was that East Timor was then followed by Sierra Leone and the Democratic Republic of the Congo (DRC) in a more robust, larger-scale, and complex form of UN peace operations. These developments spurred in succession would imply that there could be no other sustainable policy options except for UN-sanctioned peace operations. This conclusion was unequivocally associated with a variety of considerations such as (1) relative advantages the UN multilateral cooperation system enjoys, especially in terms of finances; (2) the legitimacy of the use of force; (3) joint participation of states, development agencies, and other actors, and work sharing among them; and (4) smooth transition to a post-intervention stage of reconstruction and development (Asahi 2015, 144; Sewall 2000, 40).

\section{Unprecedented Challenge for Consent and Indigenous Wisdom}

Second, as examined briefly, I have shown that the INTERFET turned out to be a success. This is the first UN-sanctioned humanitarian intervention under the Chapter VII provisions that took place in Asia in the post-Cold War period. Now I argue that it could offer a distinct "Asian model" from which a couple of important lessons could be drawn.

According to his memoirs, Kofi Annan, the then UN Secretary-General, was preoccupied with a sense of impending violence on the ground in East Timor. Annan disclosed the fact that at an early stage he acquired a tacit commitment from Australian Prime Minister John Howard and said, "Australia, who has a robust, competent military with an ability to lead the operation effectively and convincingly, would do so" (Annan 2012, 106). However, at the same time Annan honestly confessed that "the possibility of Australia's leading any potential intervention was fraught with tensions given its own status in Asia." Furthermore, Annan conceded that "they were not considered truly Asian by their neighbors, and I needed other regional powers to commit, such as Thailand, Malaysia, and Singapore." Annan went on to say that "they, in turn, would not even consider being involved-or want it to be known publicly that they were even speaking to me about it-without an explicit invitation from the government of Indonesia" (ibid., 106-107). 
An important point here is that Annan apparently understood that although any mandatory action could be taken under Chapter VII authorizations given the rapidly deteriorating humanitarian situations, consent of the host government is, nevertheless, a political "must." Indeed, Indonesia was then politically weakened because of the post-democratization turmoil that followed the breakdown of the Suharto regime. But it was not a broken state like Somalia, nor was it a warring or fragmented state like Bosnia. Indonesia remained a regional power with its military might intact. Annan confessed that he was keenly aware of the necessity of persuading President Jusuf Habibie, interim and nervous leader of Indonesia, who was under strong domestic and external pressures (ibid., 106-107). Especially, U.S. President Bill Clinton and John Howard of Australia were said to take a leading role in influencing Indonesia to accede.

There is a "hidden" story here which deserves to be told regarding the ASEAN's joint effort that led to eventual but voluntary consent of the Indonesian leaders. I argue that this was realized not by a show of force, but by the power of persuasion. In this regard, Annan's memoirs were a poor account. Rather, the genuine story was quite contradictory to Annan's narrative. In fact, some ASEAN member countries spontaneously led a quiet but robust initiative at the foreign minister level to pursue a first joint dispatch of ASEAN peacekeepers. They shared a common understanding that East Timor was part of ASEAN's regional problem and that it was in ASEAN's mutual interests to restore peace through their hands. Japan stood by and supported the ASEAN initiative "from behind." Japan, after consulting with ASEAN counterparts, made a public announcement on September 16, the day after SCR 1264 was adopted on September 15, to offer a substantial aid package to facilitate the dispatch of ASEAN troops. On October 4, Japan expressed a decision to provide US\$100 million to the ASEAN peace operation (Asahi 2015, 175-176).

To be more exact, Surin Pitsuwan, then Thai Foreign Minister and later ASEAN Secretary-General, shared this part of his experience in an open lecture held in 2007 at the Japan Institute of International Affairs (JIIA). In that lecture, Surin (2007) vividly explained the background as well as the inside story illustrating the last-ditch parleys with the Indonesian leaders in which Surin and some of his ASEAN colleagues participated. During a standstill between UN negotiators and Indonesian leaders, who strongly rejected the acceptance of an Australia-led force, a team of ASEAN foreign ministers made a whirlwind visit to Jakarta on September 7, 1999. The dispatch was realized by order of their bosses, who happened to assemble in Wellington, New Zealand in order to attend that year's APEC summit meeting. Surin explained that they struggled not only to persuade the Indonesian leaders but also to defy the latter's persistence in national sovereignty and false confidence stuck to especially by President Habibie that local security could be maintained by the strict enforcement of martial law. However, Surin said, "Eventually, Wiranto, welcoming ASEAN's 
thinking to join an Australia-led multilateral force, adds that the ASEAN soldiers come ashore ahead of other troops." Surin went on to say, "Habibie also urged an ASEAN commander to take whole command of the entire force." It was just after the conclusion of these overtures with the ASEAN representatives that the Indonesian leaders grudgingly consented to the Chapter VII measures. And, on September 15, 1999, almost a week after the proclamation of martial law in East Timor, the Security Council passed Resolution 1264. According to James Traub (2006, 108), the Australia-led force of 11,000 soldiers was "the fastest emergency development ever since the UN first sent a force into Cairo in 1960."

To sum up, I argue that two lessons could be drawn from the foregoing. First, with regards to force composition, a multilateral rather than unilateral force is far more politically desirable for the sake of confidence-building with the target country and its people. The inclusion of local recruits is an important component for successful missions. Secondly, local political practices or informal political norms should be respected so that a hard-won concession might be obtained. On Asian political soil, there is a variety of this sort. What was called the "Asian way" prevailed as a guiding principle to facilitate the consolidation or cohesiveness of the APEC forum at its incipient moment. The "face-saving" practice carried weight this time as a means for a compromise.

As a matter of course, the experience in East Timor should not pass into oblivion, and efforts should be continued to solidify a regional security framework of peace cooperation not only among the ASEAN member countries but also in a wider regional forum, such as the ASEAN plus Three or the ASEAN Regional Forum (ARF) and beyond. Moreover, I also argue that the experience in East Timor could be brought up for discussion with a view to contributing to operationalizing the concept of "the responsibility to protect," adopted in the so-called Outcome Document of the 2005 World Summit. This topic falls in the category of Pillar Two, entitled "international assistance and capacity building," part of what is called the three-pillar strategy (A/63/677), proposed by UN Secretary-General Ban Ki-moon.

\section{Pitfalls for Progress}

It is widely understood in the UN corridors that peacebuilding in East Timor has been making steady progress to date. I argue that the evolutional development combined with the changing forms of peacebuilding operations at different stages unequivocally testifies to said common understanding.

To look back, it began with the electoral mission (UNAMET) in 1999, transitioning to the multilateral force (INTERFET) in 1999, to the transitional administration (UNTAET) from 1999-2002, to Phase-I of post-independence peacebuilding (UNMISET) from 2002-2005, to one year of "stand-still" in 
peacebuilding (UNOTIL) from 2005-2006, to the Phase-II of post-independence peacebuilding (UNMIT) from 2006-2012, and eventually to the final and sustainable development stage from 2013 onward, where the East Timorese must stand on their own feet.

Within the above-mentioned sequential developments, three incidences of social unrest that need to be highlighted occurred respectively in December 2002, in April 2005, and most recently and shockingly in April to May 2006. I argue that this common phenomenon of disruptive incidence had a strong correlation with social and economic woes as well as the still fragile post-independence governance structure and especially a weak national police, although each incident took on a slightly different external appearance. For a post-conflict country like East Timor, it is especially important to attend in various ways to formerly armed groups, such as militias, guerrillas, or their bereaved families. They are presumably disgruntled with unheeded recognition or unsatisfactory treatment of their pre-independence role. As important is the provision of a "peace dividend" in kind or a sign of hope for the future. Those three incidents were truly expressions of social frustration, grievances about impoverished life, and people's despair of ongoing politics or the governing political leaders. Participants in the uproar understandably protested that they were being excluded or unduly treated.

This is especially the case with the 2006 incident, which baffled the reputation of an ever-moving-forward peacebuilding operation. When it occurred, I commented in response to press inquiries and wrote in an essay that it was obviously due to the premature withdrawal of the peacekeeping component at the close of the UNMISET in 2005 (Asahi 2015, 235-263). While some UN officials then denied it, Sukehiro Hasegawa, UN mission chief of UNMISET (2004-2005) and UNOTIL (2005-2006), seemed to acknowledge it, judging from the fact that the title of one chapter of his memoirs entitled Primordial Leadership reads, "Premature withdrawal of peacekeepers and transition to a sustainable development framework" (Hasegawa 2013, 208-246). I argue that peacebuilding and peacekeeping are mutually interlinked and reinforce each other, and that there may come a moment when the withdrawal of armed forces becomes due just after the consolidation of peace, underpinned by economic and social achievements. In this connection, Paragraph 28 of the Brahimi report unequivocally stated the following:

When complex peace operations go into the field, it is the task of operations' peacekeepers to maintain a secure local environment for peacebuilding, and the peacebuilders' task to support the political, social, and economic changes that create a secure environment that is self-sustaining. Only such an environment offers a ready exit to peacekeeping forces, unless the international community is willing to tolerate recurrence of conflict when such forces depart. History has taught that 
peacekeepers and peacebuilders are inseparable partners in complex operations: while peacebuilders may not be able to function without the peacekeepers' support, the peacekeepers have no exit without the peacebuilders' work (UN 2000).

In other words, the incident brought to light the problem of what is called "exit strategy" and signified the absence of any concrete exit strategy (from peacekeeping to sustainable development). Former President George W. Bush said that the U.S. forces would not stay any longer once it becomes unnecessary to stay. But there is no textbook for peacebuilders to rely on except for rule of thumb and actual practices in the field. The UN Secretary-General's document (UN 2001), completed based on open discussions at the Security Council, concluded with the slogan "No Exit Without Strategy (NEWS)." It is easy to say, but it's difficult to put in practice. At the same time, the document admits that there is also space for ambiguity as to when to exit, by saying that "it is in the grey area between clear success and failure that a decision becomes complex" (ibid., para. 55).

The 2006 incident started first with open petitions by disgruntled soldiers for review and improvement of their treatment. The then President Xanana Gusmão publicly intimated in the beginning that behind the movement might lie grievances against discrimination held by Easterners (lorosae) against Westerners (loromonu) within the military (F-FDTL). But their plea movements, though apparently non-political, were in due course hijacked by dangerous segments of society, namely unemployed youths on urban streets and discontented excombatants left unheeded on the periphery. And, as a result, the former lost control of the politicized movements to the latter groups. Moreover, political rivalry between President Gusmão and Prime Minister Alkarili surfaced and stiffened when the latter impinged on the former's presidential prerogative.

The fragility of government institutions, especially in the security sector, further complicated the situation. Security Council Resolution 1704, which was later adopted to establish a new UN mission (UNMIT) in order to jumpstart peacebuilding, clearly refers to the necessity of the consolidation of the security sector and especially coordination of the police and the military. It has often been said that behind the deep distrust and uncompromising feud between the two armed forces lay a competition for scarce government resources. In a resource-deficient country like East Timor, a limited number of government positions were the sole employment opportunities and a rare prize, especially for ex-Falintil fighters. However, the prototype of the national police (PNTL) was built apparently for practical reasons at the time of the UN transitional administration (UNTAET), and the cadre of police officers was recruited out of those professionals in service under the Indonesian military rule. At the same time, on the other hand, there was a strong voice on the eve of independence to repeal the establishment of a regular army (Power 2009, 330, 527). 
Despite the foregoing, this is why what is called "quick-fix" measures, which is UN jargon, are needed and considered important in the early stages of postconflict consolidation of peace. Peacebuilding may need a significant amount of time to take hold because it is not only a theoretically time-consuming process but also a physically resources-expending undertaking. I was reminded of a conversation exchanged with an inexperienced senior government official who had an apparently obsessive attitude and honestly confessed that it was just like a race against time, given the swelling expectations of people for wealth and hope after independence.

\section{Difficulties of "Getting to Denmark"}

Francis Fukuyama said, "Having taken for granted the existence of their government, people of the developed countries have almost forgotten where it came from. Even the Danes do not know how to "get to 'Denmark"' (Fukuyama 2011, 14-19). Denmark is a symbol for an ideal state of governance, which is named after a World Bank project. I argue that peacebuilding is exactly a contemporary version of "getting to Denmark." East Timor's case is quite contradictory because the difficulties of "getting to Denmark" are not amnesia but non-existence of its own experience. As Sharma eloquently stated, it is a "start from scratch".

I also argue that there must be no dismaying, even if there is no news from the ground. No news is good news as far as peacebuilding is concerned. I would argue that there are two reasons why this is so. That is, just as a dog biting a man does not contain any news value, so does steady progress in the field not merit a story on the evening news. As I said above, peacebuilding is indeed a very quiet and time-consuming process. It would be rather boring and tedious from the press' view-point, which is basically tension-happy. Therefore, the press would not be willing to report how much progress has been made in the field. This is, in truth, what the news-coverage of post-conflict peacebuilding is all about. To describe the real nature of peacebuilding, Fukuyama $(2004,88)$ maintained the following:

If we really want to increase the institutional capacity of a less-developed country, we need to change the metaphor that describes what we hope to do. We are not arriving in the country with girders, bricks, cranes, and construction blueprints, ready to hire natives to help build the factory we have designed. Instead, we should be arriving with resources to motivate the natives to design their own factory and to help them figure out how to build and operate it themselves. Every bit of technical assistance that displaces a comparable capability on the part of the local society should be regarded as a two-edged sword and treated with great caution. Above all, the outsiders need to 
avoid the temptation to speed up the process by running the factory themselves.

In addition, Fukuyama discussed at great length the modern political order that human societies have eventually reached (Fukuyama 2011). Fukuyama explained that the modern liberal democratic order is composed of a set of three political institutions: the state, rule of law, and the accountability of government. The state is about power, or to generate power, to enforce law, to deliver the services people demand, and to protect people from external threats. On the other hand, the rule of law is about checking power, and so is the accountability of government. The rule of law means that not only citizens or subjects but also rulers and kings are, without exception, subject to rules once they are enacted. The rule of law is different from the rule by law in that the latter exempts rulers and kings. The principle of accountable government is meant to set up a government which represents the will of its citizens and puts their will above that of rulers. Democracy is one form of accountable government based on procedural legitimacy.

All three institutions had their own historically accidental origins and took respectively subsequent development paths which were subject to contingency and necessity. But what is important is how to establish a good and stable balance among those three institutions. A powerful state without rule of law or an accountable government tends to become despotic or dictatorial. On the other hand, a weak state, even if lawful and accountable, could neither secure its citizens' security nor prosperity. Fukuyama therefore seemed to underscore the importance of "stateness first" (Fukuyama 2005, 84-88; Fukuyama 2015, 18-20).

Going back to state building in East Timor, Hasegawa apparently regretted that since the UN disproportionately emphasized the importance of transitional justice based on its mandate, the establishment of the judiciary system had been rather sidestepped in importance and resources allocation (Hasegawa 2013, 4345). As a result, the weak judiciary is left as a vulnerable leg of the post-conflict governance system in East Timor, together with the police organization, which is one of the problems I discussed earlier. However, it should be noted that East Timor's attempt to bring "transitional justice" has been reasonably successful despite some limitations and loose ends. It has been undertaken through combined efforts of a UN-sanctioned hybrid court to try "serious crimes" and a spontaneously generated-local movement to seek truth and reconciliation,

Furthermore, concerning the difficulties of transplanting state institutions, Fukuyama (2004, 43-91) offered a very useful perspective. That is, in the package of knowledge necessary to build state institutions, there are not only transferable but also non-transferable components. The composition or combination of these parts varies depending on the nature of each organization's specificity and transaction volume (ibid., 55-67). Fukuyama asserted that at the organizational design and management level, there is no theory to formalize the optimal 
organizational model of governmental agency due to a very delicate balance between delegated discretion needed for efficiency on the one hand, and control and supervision on the other (given the principal-agency principle). In order to reduce vast administrative costs incurred by formal rules and regulations for the latter function, the adoption of informal norms internalized within the organization could be naturally advocated. Those informal habits and norms have been unconsciously influenced by culture, which Fukuyama defined as behavior learned and passed on through generations. It is a rational, ethical habit. Fukuyama stated that although it is malleable and can be affected by developments on the levels of ideology, institutions, and civil society, it tends to change the slowest of all (ibid., 67-91).

\section{Changing Agendas with the Lapse of Time}

Lastly, I argue that there are three uneasy and interrelated problems which I believe will have long-term implications for the future of this new country (Asahi 2012, 10-22).

\section{Emerging Generational Rift?}

After the last UN mission (UNMIT) withdrew from East Timor at the end of 2012, no news-breaking headlines have appeared in news media. I personally concluded that ordinary daily life has settled and the people and the government are busy concentrating on the consolidation of institution building of the state. Politics therefore seems to be stable and on the right track. The largest opposition party, Fretilin, is now so cooperative with the CNRT-led government under the leadership of Xanana Gusmão that it virtually takes the form of a de facto coalition government with Rui Arauj, a young Fretilin member, as the new prime minister in place of Gusmão.

When José Ramos-Horta, the then incumbent president, was voted out in the first round of the 2012 presidential elections, I saw some hints of what this unanticipated news implied in Xanana's press interview, which emphasized the increasing influence of demographic change, especially that of the younger generation in politics. Then I wondered whether some time in the future Ramos-Hortas departure would be construed as a trigger for the end of the first generation of the national founders. As I predicted, Gusmão, a wise and humble politician of the first generation, followed Ramos-Horta before long and retired from his leading position.

In contrast is the rise of President Taur Matan Ruak, former commander of the Timorese armed forces (F-FDTL). While forming a new political party named the People Liberation Party (PLP), composed of the younger generation, Ruak takes an apparently defiant posture of distancing himself from the older- 
generation leaders by promoting anti-corruption campaigns targeting especially Gusmão and Mari Alkatiri, Party Secretary of Fretilin. Ruak, visiting, in order to rally grassroots support, all the local communities and villages in the countryside which total 442 , seems to have become increasingly assertive politically.

It is against this background that a third round of national elections, both presidential and parliamentary, is scheduled in 2017. This is a good sign of peace-time politics where bigger issues are addressed and decided in national elections. "Inclusive" politics is at work! An experienced local observer argued that Ruak's calculated political assertiveness would bet on the demographic shift in favor of the younger generation. He speculated that Ruak might appeal for such controversial issues that might further deepen a looming generational rift. However, Ruak did not run for the 2017 presidential election, which was held in March of this year and instead Fretilin leader Francis "Lu-Olo" Guterres was elected thanks to joint support of Gusmão and Alkatiri, political leaders of the first generation. On the other hand, Ruak is said to seek a parliamentary win, as Gusmão did in 2007, that would truly take him to a more powerful executive position (premiership). Nobody knows what will become of the series of those political events that ensue.

\section{Growing Discontent over Peace Dividends}

I was struck by an essay contributed by Haruhiko Kuroda, the president of the Bank of Japan, to a Japanese monthly opinion journal, in which he referred to an interesting policy debate with Jeffrey Sachs, held at an aid partners-meeting for East Timor, over the management of revenue from extractive resources, or in other words, how to prevent the "oil curse" (Kuroda 2015, 71).

Kuroda, then the Asian Development Bank (ADB) president, argued in support of what is the so-called Norwegian Model, the scheme the East Timorese leaders agreed on before independence to control returns from oil money so that they would be utilized in the interest of future generations. Indeed, East Timor established a petroleum fund with a view to pool all royalty revenues obtained from the possession of resources ("upstream" control) and to expend some portion of the fund for the annual budget with approval of the national Parliament ("downstream" control). Thanks to this scheme, East Timor was awarded for its excellent management of oil revenue by the Extractive Industry Transparency Initiative (EITI), an international surveillance body advocated and founded by former British Prime Minister Tony Blair that oversees the transparency of transactions of money drawn from extracted mineral resources.

On the other hand, Sachs argued against this scheme, which Paul Collier calls a "future-generations fund." Sachs maintained that the scheme would not go as well as planned but rather be prone to being siphoned off because populism is likely to be strong in an extremely impoverished country like East Timor. I am not sure how Collier and Sachs, both prominent economists, formulated their 
arguments. They might perhaps be based not on purely theoretical reasons but on empirical lessons as well.

What's happening today in East Timor, once one of the poorest countries in Southeast Asia, is a sign of a glut of money in society. This novel phenomenon has appeared due to the lifting of the upper limit of money extracted from the petroleum fund for the national budget, which was set by law at the level of 3 percent of estimated total oil assets (or ESI-Estimated Sustainable Income). It is just like "relaxing the bulb of oil money reservoir." Increased government expenditure has been used for a variety of political purposes, such as subsidies for displaced persons driven from their homes in the wake of the civil unrest of 2006 and pensions for former guerrilla fighters and bereaved families. It might be sensible to accuse Gusmão of such an easy method of political management, but it seems to me that this represents a hidden aspect of his political style; namely "politics of compassion," or showing great care for the socially weak and his faithful followers. A general trend of generous dispersal of increased budgets has also developed to date, and budgeted money bloated by an extra zero is now dispersed mainly through infrastructure-related programs. This uneasy development is spurred and amplified by a flawed system of government procurements. This could be called "downstream" paralysis.

Since money moves and settles somewhere in this way, most of the money seems less likely to fall into the hands of the people at the bottom or on the periphery of society-most of whom have an income that is around the poverty line. It is against this backdrop that there is growing criticism leveled at the fact that a wealth divide has increasingly widened. Rumors about "corruption," a disposition or an actual attempt prevailing inside the government to exploit public money for personal interests, are more frequently heard. The government is cautious, as a matter of course, about the spread of corruption and has put into practice anti-corruption measures such as the strengthening of the AntiCorruption Commission. Fighting corruption is a race against time. It is therefore imperative that tangible results be achieved from anti-corruption campaigns before corruptive habits and practices take hold.

\section{Uneasy Future of the Youth Problem}

Last but not least, the youth problem consists of three interrelated aspects. These are (1) unemployment; (2) a peculiar youth culture, or youths immersed in martial arts who gather in the streets of urban areas; and (3) an identity crisis that plagues a generation of school-age youths confounded by flawed language education. These phenomena are not necessarily confined to East Timor, but are also seen widely in other conflict-ridden areas such as Palestine. I argue that the youth problem is now one of the biggest development challenges the world has to grapple with.

Firstly, one cause of the youth problem is an absolute shortage of 
employment opportunities. The unemployment rate in urban areas is 16 percent, more than twice as high as in the countryside (SEFORE and the National Statistic Directorate, the Government of Timor-Leste 2010). Since East Timor has no major industry to speak of except for agriculture, job creation is not just an economic interest per se, but also a social concern since solutions to unemployment lead to the realization of social stability. The unemployment problem therefore takes on a political dimension in the context of post-conflict peacebuilding. Although a variety of job-creation measures have presumably been taken to date, it is regrettable that little effort seems to have been made to enhance agriculture to a self-sustaining level on a nation-wide scale, although it is critical from the view point of employment policy.

Secondly, visitors to East Timor might be a bit frightened upon seeing for the first time the bizarre scene of youngsters swarming in groups in the streets showing off martial arts moves-the so-called martial arts groups. Full attention was paid to this dismal phenomenon and some initiative, although weak in tone, to rectify the problem was taken on the eve of the conclusion of the UNMISET operation. It was these same youths who played a leading role in the rampage in 2006. According to UNICEF's findings, the youths have suffered the after-effects of having failed to form their own identities due to the turbulent and unstable social circumstances facing them. UNICEF's preliminary conclusion also detected a resulting tendency: the youths have a natural preference for martial arts because they found their abstract charm much closer and more familiar to them than Gusmão, an actual guerrilla war hero still admired by the older generation of their parents (Kukita 2012, 48-90).

The third concern is related to the language policy adopted in East Timor on the eve of independence. In this connection, let's compare East Timor with Mozambique. Mozambique is another Portuguese-speaking country which has now adopted English as a working language. It applied for and obtained membership in the Commonwealth of Nations in 1995. As is seen above, Mozambique strikes a sharp contrast to East Timor in that its drastically changed language policy has led in part to post-conflict prosperity. On the other hand, East Timor faces a dilemma, if not serious trouble, in its struggle with the dissemination of the Portuguese language, designated as an official language, together with Tetun, the main local language. Flawed and unbalanced language education was apparently one of the causes of poor outcomes in literacy improvement among school children. As a result, only one in four East Timorese understands this official language. Some of the main reasons are due to an absolute shortage of local teachers who can speak and teach Portuguese and the absence of a high-quality curriculum (ibid., 75-141).

This policy has also caused serious collateral damage to the teaching of the Tetun language, which is used in daily life. A survey unveiled a shocking reality concerning the literacy level of school children and released findings that nearly 
every first-grade student in elementary school can barely read a word at the end of their first year of education. Language education is a very tough aid-policy subject. Basically, outsiders must be cautious about comments concerning other countries' language policies, which may involve a variety of complicated and sensitive elements. They are likely to create a very sensitive political reaction. This is also the case with East Timor (ibid., 132).

\section{Conclusion}

I have discussed at length several issues that outline progresses made so far and problems yet to be addressed at the stage of "post-conflict consolidation for peace" of this new country. As the readers may have noticed, there are some commonalities with other cases, as well as East Timor-specific elements. The case of East Timor represents a success model of the UN-led peace operations whose advantages are pointed out by James Dobbins (2007). On the other hand, however, state building, as Francis Fukuyama paraphrased as "getting to Denmark" (2004), is no easy task at all for East Timor. It is indeed not only time-consuming but also resources-expending. As Kamalesh Sharma pointedly refers to "start from scratch," what matters with East Timor is not amnesia but non-existence of their experiences. In addition, the East Timorese must simultaneously engage in nation building, which can never be undertaken by outsiders because it can only "evolve out of an unplanned historical-evolutionary process" (Fukuyama 2006, 3).

In 2017, East Timor celebrates its fifteenth anniversary of independence. But East Timor is on a halfway path and will still have to face up to uncertainties that follow.

\section{Notes}

1. The word "peace operation" has a broad meaning covering a variety of peace-related activities such as peacemaking, peacekeeping, peacebuilding, and the like. And so, its usage is exchangeable with that of these words, as is often seen among peace studies scholars and students.

2. The word "Timor-Leste" literally means East Timor. "Timor-Leste" is the official name of East Timor and comes from the Portuguese language. These two words are used exchangeably. 


\section{References}

Annan, Kofi. 2012. Interventions: A Life in War and Peace. London: Penguin Press.

Asahi, Hideaki. 2012. "An Uneasy Future for East Timor: Ten Years after Independence." JIIA Colum, Japan Institute of International Affairs, Tokyo, Japan, April 4. http:// www2.jiia.or.jp/en/pdf/research/20120628e-An_Uneasy_Future_of_East_Timor.pdf (accessed November 18, 2016).

Asahi, Hideaki. 2015. Heiwakochik u-Ron-wo-Saikouchiku-suru: Zoho-Kaitei-Ban

[Rebuilding Peace Building Theory: Revised Edition]. Tokyo: Nihon-Hyoronsha.

Chesterman, Simon. 2007. “East Timor." In United Nations Interventionism: 1991-2004, eds. Mats Berdal and Spyros Economides, 192-216. Cambridge: Cambridge University Press.

Dobbins, James, Seth Jones, Keith Crane, Andrew Rathmell, Brett Steele, Richard Teltschik, and Anga Timilsina. 2005. The U.N.s Role in Nation-Building: From the Congo to Iraq. Santa Monica, CA: Rand.

Economist. 2013. "Timor-Leste and Australia: Bugs in the pipeline" 407 (8839): 24.

Fukuyama, Francis. 2004. State-Building - Governance and World Order in the $21^{\text {st }}$ Century. New York: Cornell University Press.

Fukuyama, Francis. 2005. “Building Democracy after Conflict: 'Stateness' First.” Journal of Democracy 16 (1): 84-88.

Fukuyama, Francis. 2006. "Introduction: Nation-Building and the failure of Institutional Memory." In Nation-Building - Beyond Afghanistan and Iraq, ed. Francis Fukuyama, 1-18. Baltimore: Johns Hopkins University Press.

Fukuyama, Francis. 2011. The Origins of Political Order: From Prehuman Times to the French Revolution. New York: Farrar, Straus and Giroux.

Fukuyama, Francis. 2015. "Why Democracy is Performing So Poorly." Journal of Democracy 26 (1): 11-20.

Hasegawa, Sukehiro. 2013. Primordial Leadership: Peacebuilding and National Ownership in Timor-Leste. Tokyo: United Nations University.

Huntington, Samuel. 1993. The Third Wave: Democratization of the Late $20^{\text {th }}$ Century. Norman, Oklahoma: University of Oklahoma Press.

Ignatieff, Michael. 2003. "State failure and nation building." In Humanitarian Intervention, eds. J.L. Holzgrefe \& Robert Keohane, 299-321. London: Cambridge University Pres.

Kawakami, Kazuhisa. 2003. "Setting-up of UNTAET: Post-UNAMET Planning, Drafting, Resolutions, and Finance." In The United Nations Transitional Administration in East Timor (UNTAET): Debriefing and Lessons: Report of the 2002 Tokyo Conference, eds. Nassrine Azem and Chang Li Lin, 41-45. Leiden: Martinus Nijhoff.

Kennedy, Paul. 2006. The Parliament of Man: The Past, Present, and Future of the United Nations. New York: Random House.

Knaus, Gerald, and Marcus Cox. 2005. "The 'Helsinki Moment' in Southeastern Europe." Journal of Democracy 16 (1): 39-53.

Kukita, Jun. 2012. Higashi-Timor-no-Genba-kara: Kodomo-to-Heiwakouchiku [From the Field of East Timor: Children and Peacebuilding]. Tokyo: Sotokoto Press.

Kuroda, Haruhiko. 2015. "Sugao-no-Ekonomisuto-tachi, No.1 [The Real Faces of Economists, No.1.]." Chuo-Kohron 129 (6): 64-71. 
Kuroda, Haruhiko. 2011. "Keynote speech by ADB President Haruhiko Kuroda at the 2011 Timor-Leste Development Partners Meeting on July 12, 2011, Dili, Timor-Leste." Asian Development Bank, July 12. http://www.adb.org/news/speeches/vision-asia2030-investing-timor-lestes-future (accessed November 18, 2016).

Paris, Roland. 2005. "Wilson's Ghost: The Faulty Assumptions of Post-Conflict Peacebuilding." In Turbulent Peace: The Challenges of Managing International Conflict, eds. Chester A. Crocker, Fen Olser Hampson, and Pamela Aall, 735-764. Washington, D.C.: United States Institute of Peace.

Paris, Roland, and Timothy D. Sisk. 2009. "Introduction: Understanding the contradictions of post-war statebuilding." In The Dilemmas of Statebuilding: Confronting the contradictions of postwar peace operations, eds. Roland Paris and Timothy D. Sisk, 1-20. London: Routledge.

Power, Samantha. 2008. Changing the Flame: Sergio Vieira de Mello and the Fight to Save the World. London: Penguin Press.

SEFORE (The Secretariat of State for Vocational Training and Employment) and the National Statistic Directorate, the Government of Timor-Leste. 2010. “Timor-Leste Labor Force Survey 2010.” http://dne.mof.gov.tl/published/TLS\%20Labour\%20 force $\% 20$ survey\%202010/Timor-Leste\%20-Labour\%20Force\%20Survey\%20 Report\%20-\%202010.pdf (accessed November 18, 2016).

Sewall, Sarah. 2000. "U.S. Policy and Practice Regarding Multilateral Peace Operations." Carr Center for Human Rights Policy Working Paper 01-3, Harvard Kennedy School of Government.

Surin, Pitsuwan. 2007. "A Chartered ASEAN and East Asia Community: A Way Forward." JIIA Forum, Japan Institute of International Affairs, Tokyo, Japan, December 12. http://www2.jiia.or.jp/EVNT/forum_play.php?id=197\&v=071213e-pitsuwan.mp4 (accessed November 21, 2016, members only).

Traub, James. 2006. The Best Intentions: Kofi Annan, and the UN in the Era of American World Power. New York: Farrar, Straus, Giroux.

UN (United Nations). 2000. "Report of the Panel on United Nations Peace Operations" (A/55/305-S/2000/ 809). August 21. http://www.un.org/en/ga/search/view_doc.asp? symbol=A/55/305\&referer=http://www.futurepeaceops.org/project/brahimi-report2000/\&Lang=E (accessed November 18, 2016).

UN (United Nations). 2001. "Report of the Secretary-General: No Exit Without Strategy: Security-Council Decision-Making and the Closure or Transition of United Nations Peacekeeping Operations" (S/2001/394). April 20.

UN (United Nations). 2009. "Report of the Secretary-General: Implementing the responsibility to protect” (A/63/677). January 12.

Wills, Greg. 2014. Why States Recover: Changing walking Societies into Winning Nations, from Afghanistan to Zimbabwe. London: Hurst.

Hideaki Asahi is currently an adjunct fellow of the Japan Institute of International Affairs (JIIA) and was a professor of international politics at the Graduate School of Arts and Sciences at the University of Tokyo. Prior to academic life, he was in the diplomatic service beginning in 1971 when he entered the Ministry of Foreign Affairs of Japan. He served in overseas postings including Washington, D.C., 
Teheran, Geneva, and New York. In 2004, he was appointed as Japan's first ambassador to Timor-Leste and then retired from the diplomatic service in 2006.

Submitted: September 8, 2016; Revised: December 1, 2016; Accepted: March 8, 2017 